\title{
Control e imagen real en la corte de Felipe IV (1621-1626)
}

\author{
Javier Portús Pérez \\ Museo Nacional del Prado \\ javier.portus@museodelprado.es
}

Recepción: 29/06/2015, Aceptación: 22/07/2015, Publicación: 22/12/2015

\begin{abstract}
Resumen Velázquez, que llegó a Madrid en 1623 para trabajar al servicio del rey.

Palabras clave

leyes antisuntuarias; indumentaria; retrato cortesano; Velázquez
\end{abstract}

Con el acceso al trono de Felipe IV llegaron al poder unas nuevas élites políticas, que para legitimarse promovieron numerosas medidas relacionadas no sólo con la administración del estado sino también con la economía, el uso de productos suntuarios, etc. En ese contexto se produjeron cambios importantes en la indumentaria, que cambiaron el «paisaje social» de la corte, y que condicionaron los primeros retratos cortesanos de

\begin{abstract}
Control and royal image making at the court of Felipe IV (1621-1626)

With the accession to the throne of Felipe IV, new political élites were established. In order to legitimise themselves, they promoted different measures concerning the administration of the state, its economical management, the use of sumptuous products, etc. Within this framework, important changes in the use of attire were introduced, which modified the «social landscape» of the court, and which conditioned the early courtly portraits created by Velázquez, who arrived to Madrid in 1623 in order to offer his service to the King.
\end{abstract}

\section{Keywords}

counter-sumptuous laws; attire; courtly portrait; Velázquez 
La muerte de Felipe III a finales de marzo de 1621, y su sucesión por su hijo Felipe, que aun no había cumplido 16 años, dio lugar a un periodo extraordinariamente interesante desde muchos puntos de vista. Los años siguientes contemplaron importantes cambios en la política de la Monarquía, y la sustitución de las antiguas élites por otras nuevas. Esa nueva situación política se tradujo en transformaciones destacadas en el paisaje cotidiano de los españoles, pues afectaron a temas tan relacionados con la vida diaria como son los que tienen que ver con el traje y los usos suntuarios. Al mismo tiempo, en esos años Velázquez entró a trabajar al servicio del rey, y con él se produjo un cambio notable en la construcción de la imagen real y cortesana, cambio que refleja de manera muy sensible los nuevos ideales políticos. Los primeros años de la década de 1620 han sido también una de las épocas doradas de la historia celebrativa de la corte española, pues desde 1622 hasta 1626 se sucedieron grandes y costosísimas festividades, algunas de las cuales convivieron en el tiempo con diversas medidas para controlar el gasto en objetos de lujo y formas de ostentación entre la población.

Para gobernar, Felipe IV se apoyó en personajes como Baltasar de Zúñiga y el conde duque de Olivares, que sería su mano derecha durante veinte años. El nuevo gobierno se caracterizó por su visión crítica respecto de los gobernantes anteriores, y por una decidida voluntad reformista. ${ }^{1}$ En los meses siguientes se sucedieron a gran velocidad las destituciones de cargos importantes de la administración anterior, los nombramientos de nuevos ministros y altos funcionarios, y la promulgación de leyes tendentes a mejorar la administración del estado y las relaciones económicas. Se tomaron medidas muy duras contra algunos de los personajes más destacados del reinado de Felipe III, a los que se acusaba de la decadencia en la que había caído el país. Entre esas medidas figura el destierro del duque de Uceda, que había sido favorito del rey, la prisión del duque de Osuna o la ejecución de Rodrigo Calderón. Todo ello dio como resultado una drástica renovación del estado y la sustitución de las antiguas élites administrativas por otras nuevas, con un alto grado de profesionalización. Las cartas de Andrés de Almansa, o diferentes colecciones de noticias, informan cumplidamente de estos hechos, que se fueron sucediendo de manera rápida e implacable. ${ }^{2}$

Paralelamente, se tomaron medidas de gran alcance simbólico, como la obligación de que los ministros declarasen su patrimonio al acceder al cargo, la creación de una Junta de Reformación o una serie de leyes encaminadas a limitar el lujo en el vestido y en los ajuares. Leyes que sólo pueden ser entendidas en relación con el contexto de control, renovación y legitimación que imponen las medidas anteriores. Desde un punto de vista simbólico, fueron normas muy importantes, pues afectaron a la imagen que transmitía la corte. ${ }^{3}$ Un extranjero que

1. Elliott (1998).

2. Las cartas de Almansa están recogidas en Simón Díaz (1982: 118-262).

3. Sobre las leyes antisuntuarias, ver Puerta (2014). 
hubiera estado en Madrid en 1618 y no hubiera vuelto hasta el verano de 1623, habría notado extraordinarios cambios, que afectaban no sólo a la composición del gobierno, sino también al aspecto de los cortesanos y hasta la propia trama urbana de la ciudad, que en 1619 había visto cómo se concluía la Plaza Mayor. Las leyes antisuntuarias que se promulgaron al inicio del reinado de Felipe IV constituyen uno de los principales ejemplos que nos ha dado la historia de España de cómo el ideario político puede reflejarse en los usos indumentarios, y cómo ambos condicionan también el retrato cortesano.

Nada hay mejor para comprender el ideal de reforma, austeridad y compromiso público con que se inauguró el reinado de Felipe IV que leer las sucesivas normas sobre trajes y comprobar su repercusión en la imagen de los cortesanos. En los meses siguientes al acceso del rey al trono se sustituyeron las calzas por los llamados gregüescos. Aquellas eran una prenda que cubría las piernas por encima de las rodillas, solían tener bastante anchura y, frecuentemente, eran de materiales vistosos y caros. ${ }^{4}$ Con ellas aparece vestido el rey en Felipe IV y el enano Soplillo, de Rodrigo de Villandrando (Museo del Prado, Fig. 1). Los gregüescos eran más largos, más estrechos y en general mucho más discretos, de acuerdo con los nuevos ideales. El comienzo oficioso de esa nueva moda tuvo lugar el 25 de septiembre de 1622, con motivo de la boda, en el Alcázar, de Isabel de la Cueva y el marqués de Javalquinto. Entonces, se nos dice, «fue la primera ocasión en que todos los señores sacaron calzones y ropillas cortas». ${ }^{5}$

4. Bernis (1994 y 2001).

5. Noticias 1942, p. 36. 


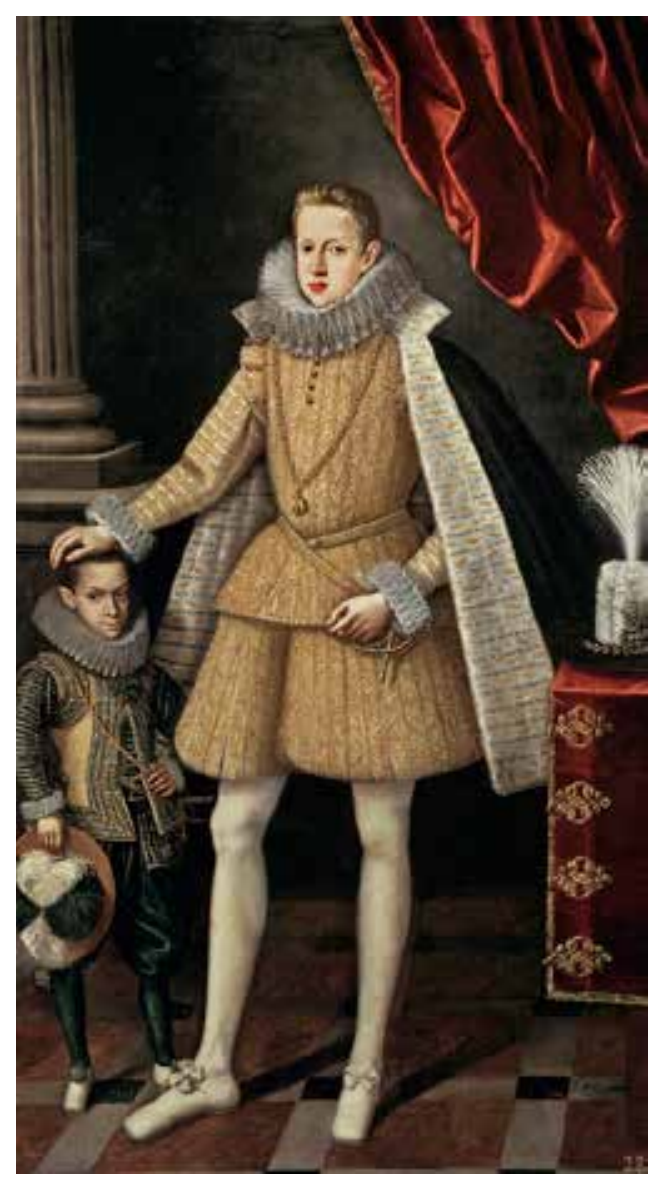

Figura 1.

Rodrigo Villandrando, Felipe IV con el enano Soplillo, h. 1620, Madrid, Museo Nacional del Prado.

El conjunto de normas más notable se acordó por la Junta de Reformación en el otoño de $1622^{6}$ y se firmó el 10 de febrero de 1623, unos meses antes del establecimiento de Velázquez en la corte. ${ }^{7}$ Incluía disposiciones de importancia desde el punto de vista de la administración pública, de la economía general o de la demografía, y todas ellas estaban guiadas por principios como la austeridad y la racionalización. Se reducían los oficios a la tercera parte; se limitaba a treinta el número

6. Almansa, Carta nona.., en Simón Díaz (1982: 180).

7. "Don Felipe, por la gracia de Dios..." (Medidas para la "conservación y aumento" de nuestros reinos), s.l., s.i., s.a. (1623). 
de días que podía permanecer en la corte un pretendiente cada año; se procuraba que los nobles atendieran sus estados, prohibiéndoles vivir en Madrid si no demostraban la necesidad de hacerlo; se limitaba a dieciocho los servidores que podían acompañar públicamente a un señor; se dictaban varias medidas tendentes a estimular la demografía, etc.

Muchas de las disposiciones trataban de limitar el ajuar doméstico y el exceso de gasto indumentario, controlando, por ejemplo, el excesivo uso de oro y plata. Entre las numerosas normas sobre trajes, el punto 9 prohibía «el uso de oro y de la plata, en tela y guarnición, dentro y fuera de casa, y en todo y cualquiera género de vestidos (...) exceptuando el culto divino, los trajes de guerra, y aderezos de la caballería». El siguiente vedaba "guarniciones en los vestidos, ni pasamanería de oro, plata o seda»; y el número 12 afectaba a vestidos y otros bienes de ajuar procedentes del extranjero. La disposición más importante fue la número 14: «Item mandamos que todas y cualesquier personas de cualquier estado, calidad o condición que sean, hayan de traer y traigan valonas llanas, y sin invención, puntas, cortados, deshilados, ni otro género de guarnición, ni aderezadas con goma, polvos, azules, ni de otro color, ni con hierro; pero bien permitimos que lleven almidón». Significaba la defunción de los complicados y costosos cuellos de lechuguilla, y su sustitución por un tipo de prenda mucho más sencilla y barata. Dado el altísimo coste de todas las prendas indumentarias de lujo y la dependencia que en ese campo tenía España con respecto a zonas como Flandes, estas medidas buscaban proteger tanto la economía nacional como la doméstica, pues, como se dice en ese documento, esos y otros gastos suntuarios "consumen las haciendas». Además, se dice, el tiempo y la costumbre había convertido prácticamente en obligatorios gastos que teóricamente eran optativos. Es decir, a la hora de leer este y otros conjuntos de medidas antisuntuarias que se tomaron durante el Siglo de Oro, no hay que ver en ellas únicamente una expresión del afán controlador del estado, o un reflejo de los problemas económicos por los que atravesaba el mismo, sino que hay que vincularlas también con el concepto de «aparentar» y con el progresivo valor que los objetos suntuarios tenían dentro de esa carrera de apariencias. El texto de la pragmática es claro al respecto:

Item, porque el abuso y exceso en los criados, alhajas y adornos de las casas, en los trajes de hombres y mujeres, se han experimentado muchos años, así en el gobierno y buena disposición en que debe estar, como en las costumbres y en las haciendas, pues siendo gastos voluntarios introducidos una vez, se han hecho tan precisos, que es una de las mayores cargas que tienen los vasallos, en que también son perjudicados el comercio y las artes. ${ }^{8}$

Lo que diferencia esta pragmática de otras colecciones de medidas similares, como las que se promulgaron en 1600 y 1611, fue su inmediata efectividad, al

8. Idem, fol. $7 \mathrm{r}$. 
menos en lo que se refiere a cuestiones indumentarias. Esa efectividad hay que verla con el trasfondo de la necesidad que las nuevas élites políticas tenían de que se advirtiera de manera rápida y eficaz su voluntad de cambio, y se relaciona también con su necesidad de legitimación. Así, la disposición sobre los cuellos se hacía efectiva a partir del 1 de marzo, y fueron el rey y sus hermanos los primeros en dar ejemplo, acudiendo por la tarde al convento del Ángel de la Guarda vestidos de esa manera. Seis días después, ambos fueron de esa guisa al colegio de Santo Tomás. ${ }^{9}$ Era un acto público, y dado que fue presenciado por "toda la corte», sancionó definitivamente la necesidad de utilizar esa modalidad de cuello. Lejos de ser un simple objeto indumentario, la valona, a principios del reinado de Felipe IV, constituía un auténtico símbolo de los nuevos tiempos y de las intenciones de austeridad, racionalidad y buen gobierno con las que había empezado el reinado.

Las consecuencias de estas leyes para la imagen de la corte se pueden advertir bien comparando, por ejemplo, el retrato de Felipe IV que firmó Rodrigo Villandrando en 1622 (Colección particular, Fig. 2) con los primeros retratos del monarca por Velázquez (Nueva York, Metropolitan Museum of Art, Fig. 3).

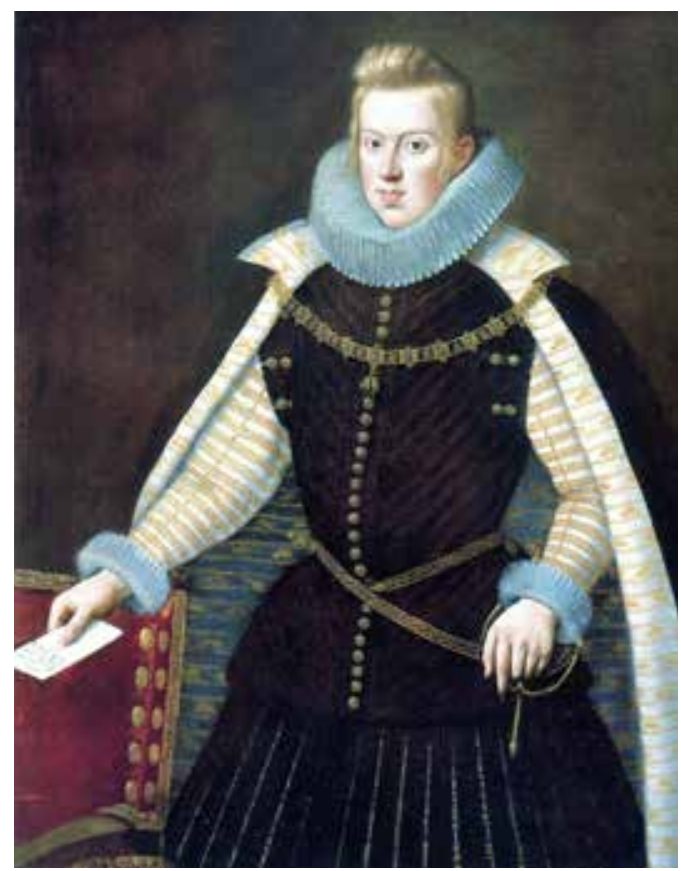

Figura 2.

Rodrigo Villandrando, El rey Felipe IV, 1622, Colección Particular.

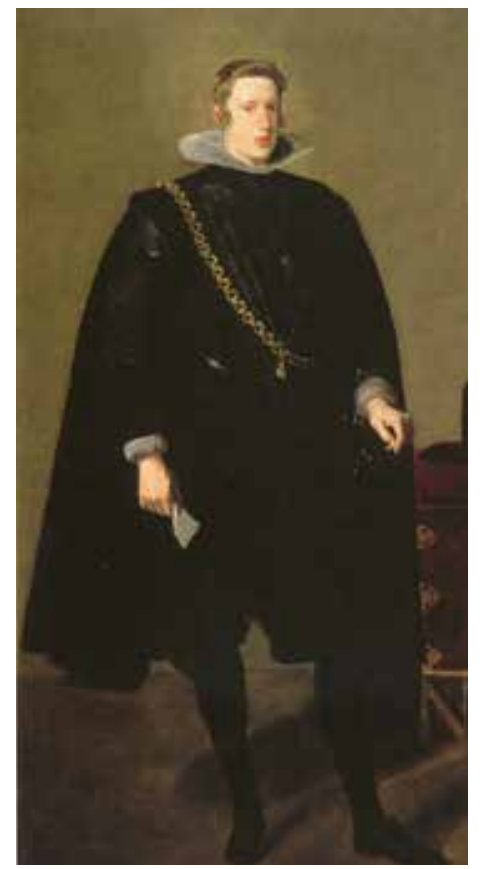

Figura 3.

Diego Velázquez, Felipe IV, 1624, Nueva York, Metropolitan Museum of Art.

9. Noticias 1942, p. 49. 


\section{Esplendor ceremonial}

El Siglo de Oro español fue un momento de fuertes contrastes, y el inicio del reinado de Felipe IV no es una excepción. Al mismo tiempo que se tomaban las medidas anteriores, tendentes a limitar el gasto, la corte atravesaba por una de sus épocas más brillantes en lo que se refiere a la cultura festiva. Poco antes de la llegada del nuevo rey al trono, en 1619, acabaron las obras de la Plaza Mayor, que en adelante se convertiría en el principal escenario de una ciudad que en las décadas siguientes multiplicó el número de sus celebraciones públicas. Estas fueron de naturaleza muy variada, y con mucha frecuencia implicaban a los reyes. En 1622 fueron canonizados conjuntamente en Roma cinco santos. Cuatro de ellos eran españoles: san Isidro Labrador, los jesuitas san Ignacio y san Francisco Javier, y santa Teresa de Jesús. Los tres últimos se consideraban bastiones de la iglesia contrarreformista, y el primero era el patrón de Madrid. Las fiestas con las que la corte celebró esas canonizaciones se cuentan entre las más importantes de ese siglo, y consistieron en ceremonias litúrgicas, representaciones teatrales, certámenes poéticos o procesiones que recorrieron las calles y plazas de la ciudad, que se engalanaron con una gran cantidad de arcos triunfales y altares efímeros. Con el contexto de austeridad moral con que comenzó el reinado se puede relacionar la prohibición del rey de que el ayuntamiento de Madrid hiciera un juego «de cañas y toros», y su recomendación de que ese gasto se emplee en «la solemnidad de la procesión y en distribución de limosnas». ${ }^{10}$ Pero, sin embargo, hay que destacar el enorme gasto que se ocasionó y el deslumbrante despliegue de riquezas, que hacen que esas celebraciones no admitan comparación con ninguna de las que habían tenido lugar en la ciudad. ${ }^{11}$ También es de señalar la activa presencia del rey, que participó en los actos principales, como la procesión conjunta de los cinco santos, a la que se unió en la Plaza Mayor, o el certamen poético del Ayuntamiento, que se celebró en el palacio real. Felipe IV manifestó un deseo expreso de convertir las celebraciones en una ocasión de gloria para la monarquía, y las aprovechó para hacer su gran presentación pública ante sus súbditos. Hacía sólo un año que había llegado al trono, y las canonizaciones fue una de las primeras ocasiones en las que se dejó ver. En adelante, con mucha frecuencia aprovecharía actos públicos de naturaleza religiosa para presentarse ante el pueblo, como las procesiones del Corpus, visitas al santuario de Atocha, beatificaciones, etc. A través de estos poderosos intermediarios devocionales subrayaba su compromiso con la religión católica.

Durante el año siguiente se dieron nuevas ocasiones de contradecir esos propósitos de austeridad. La más importante se produjo con motivo de la visita a Madrid de Carlos, príncipe de Gales, que se prolongó desde el 19 de marzo hasta el 9 de

10. Archivo de la Secretaría del Ayuntamiento de Madrid, Libro de acuerdos, no 38, fol. 539r. 11. En el caso de Ayuntamiento, nos queda una relación puntual de los gastos en el Archivo de la Secretaría de la Villa de Madrid, Sig. 2-272-30. 
septiembre. Llegó a la corte con objeto de solicitar a la infanta María en matrimonio, y su estancia dio lugar a uno de los periodos festivos más intensos y costosos de la historia de la ciudad. Los agasajos del rey y de su entorno al príncipe fueron numerosísimos y tomaron la forma de banquetes, juegos caballerescos, procesiones, etc., que se sucedieron de manera ininterrumpida durante los seis meses en los que estuvo en la ciudad. ${ }^{12}$ Con ese tipo de celebraciones estaba íntimamente asociada una cultura de la ostentación y el regalo, que tuvo uno de sus mayores exponentes en la llamada Venus del Pardo, de Tiziano (París, Museo del Louvre). Este había sido uno de los cuadros más estimados por Felipe III, y fue uno de los regalos con que agasajó su hijo al príncipe de Gales cuando se despidió de él.

A imitación del rey, los nobles también se mostraron espléndidos ante el príncipe inglés. El Almirante de Castilla le organizó un costoso torneo, el duque de Medina Sidonia envió 24 caballos desde Andalucía, el conde de Monterrey agasajó al séquito inglés con uno de los banquetes más fastuosos que recordaba la corte. En todo este gasto y este esplendor no hay que ver sólo manifestaciones de amistad, cortesía y generosidad, pues latía también el deseo de deslumbrar al visitante y de mostrar el poder de la corte española. El asunto tenía también sus implicaciones religiosas, como nos muestra la procesión del Corpus que se celebró ese año. Esa era una fiesta profundamente arraigada en la España de la Contrarreforma, pues defendía uno de los dogmas más combatidos por los protestantes, como es el de la presencia de Cristo en la Sagrada Forma. De su importancia da cuenta el hecho de que era la ocasión elegida por Felipe IV para presentarse ante sus súbditos todos los años, puesto que participaba en la procesión, cerca de la custodia. En el caso de la que tuvo lugar en 1623, fue probablemente la procesión del Corpus más espléndida que ha tenido lugar en Madrid, ya que se utilizó como instrumento para deslumbrar al príncipe Carlos, al tiempo que la ciudad afirmaba su fe católica ante el hereje anglicano.

En años posteriores se sucedieron ocasiones parecidas, y la crónica de esa primera etapa del reinado está repleta de actos festivos de diversa índole. Además de los que tenían lugar con motivo de fiestas periódicas, como el citado Corpus o las visitas al santuario de Atocha, los había de naturaleza religiosa, como el auto de fe que se celebró en 1624 o la beatificación de san Francisco de Borja en 1625; de carácter político, como el recibimiento de don Carlos, archiduque de Austria en 1624, o la celebración de la victoria de Fernández de Córdoba contra los alemanes.

En 1626 llegó a Madrid el cardenal Francesco Barberini, enviado por el papa. Desde varios puntos de vista, su visita era equiparable a la que había hecho el príncipe de Gales tres años antes. De su séquito formaba parte Cassiano dal Pozzo, una de las figuras principales del mundo intelectual y coleccionista romano de esos años. Gracias al diario que dejó este escritor, podemos seguir paso a paso las actividades de Barberini en la ciudad y advertir cómo su estancia se desarrolló entre continuas visitas a las casas aristocráticas, agasajos sin fin y una inagotable serie de intercambios de re-

12. Las descripciones de los mismos en Simón Díaz (1982: 197 y ss). 
galos. Probablemente no exista un documento que nos informe tan fielmente como esta crónica del alto consumo de lujo que existía en la corte al inicio del reinado de Felipe IV. Todo era intercambiable: joyas, obras de arte, perfumes, relicarios, objetos de devoción, búcaros novohispanos y porcelanas orientales, relojes e instrumentos científicos, plantas y rarezas de historia natural. Sólo hubo dos personajes que se mantuvieron al margen de ese trasiego de objetos: el conde duque de Olivares y su mujer. Según Dal Pozzo, «tiene en esto de no aceptar regalos mucha rigidez el conde de Olivares, así como su familia, y con este comportamiento mantiene con gran rigor la norma de favorecer sólo a quien considera más digno y sirve mejor a su Imperio».13

La historia nos dice, sin embargo, que esa formalidad de rechazar presentes no le impidió acumular numerosos cargos y un extraordinario poder, que en muchos casos manifestó favoreciendo el desarrollo de la carrera política de sus allegados.

Mientras que la acción política y legislativa de comienzos del reinado de Felipe IV nos habla de un ideal de austeridad, racionalidad administrativa y control del gasto; la actividad pública emite un mensaje distinto. Un mensaje que nos habla del «derroche» como una característica inherente a la corte, la cual sólo sabía manifestarse apropiadamente a través del esplendor, la riqueza y la magnificencia, todos ellos atributos del poder. Pero no debemos ver en esta dicotomía entre los anhelos y la realidad un signo de hipocresía, ingenuidad o impotencia. Nos sirve sobre todo para comprender dónde estaban algunos de los márgenes de la actuación política y económica en un estado absolutista.

\section{Pasión coleccionista}

Durante esos años, la nueva corte de Felipe IV estaba ofreciendo los primeros síntomas de un fenómeno que con el paso del tiempo se convertiría en una de sus señas de identidad histórica: el amor por la pintura. La relación de los reyes de la Casa de Austria con este arte había sido muy estrecha durante los reinados de Carlos V y Felipe II, pero se había relajado algo en la época de Felipe III. ${ }^{14}$ Consta el aprecio de este rey por la Venus del Pardo que su hijo regaló a Carlos de Inglaterra; pero durante su reinado no se produjo un incremento significativo de cuadros de grandes maestros europeos, e incluso dos de las joyas de la colección real sufrieron una fortuna adversa. Una de ellas era el conjunto formado por El rapto de Ganimedes y Leda y el cisne, de Correggio, obras maestras de la pintura mitológica renacentista que Felipe III regaló en 1604 a su primo Rodolfo II. El otro conjunto son las llamadas "poesías", o conjunto de seis cuadros mitológicos que Tiziano pintó para Felipe II y que su hijo escondió debido a su contenido erótico ${ }^{15}$ (Fig. 4). Durante muchos años, nadie las pudo ver.

13. Pozzo (2004: 176).

14. Morán (1997).

15. Marías y Salas (1992: 142). 


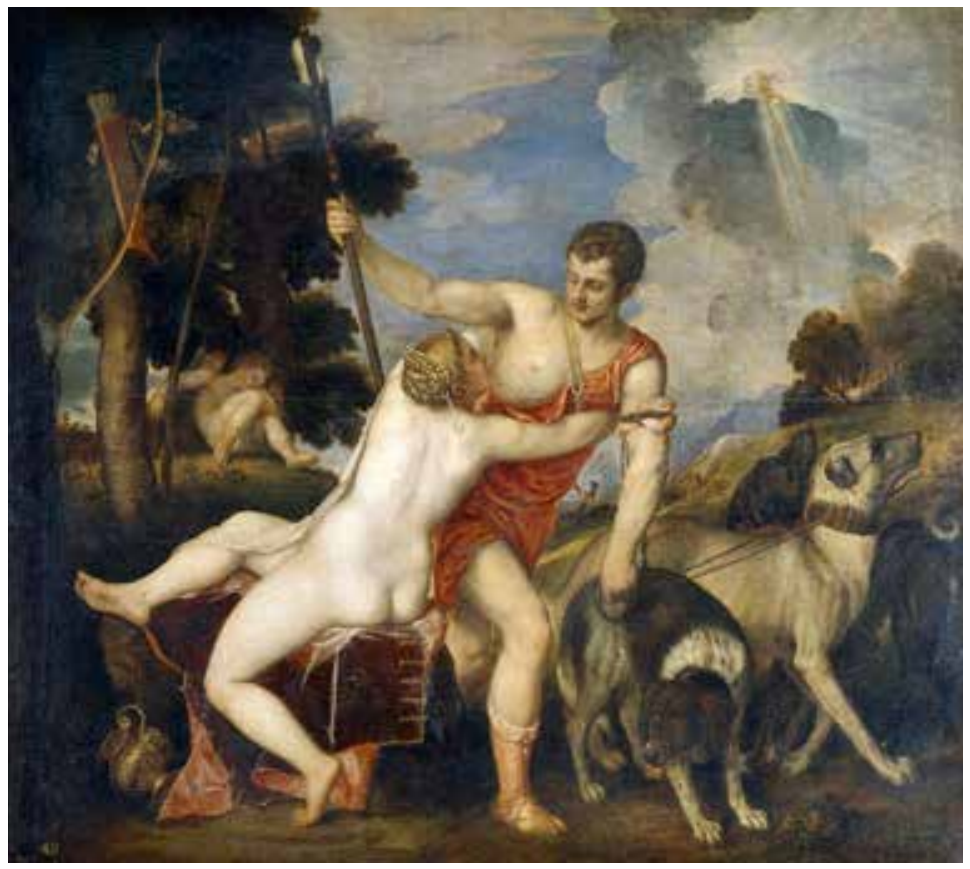

Figura 4.

Tiziano, Venus y Adonis, h. 1554, Madrid, Museo Nacional del Prado.

Aunque se dispersaron a principios del siglo XVIII, hasta entonces fueron uno de los grandes orgullos de la colección real de pintura y el núcleo en torno al cual se organizó el extraordinario conjunto de obras mitológicas del Alcázar de Madrid. ${ }^{16}$ Curiosamente, una de las primeras medidas que se tomaron durante el reinado de Felipe IV relacionadas con el patrimonio pictórico real fue sacar a la luz estas obras, creando para las mismas un contexto coleccionístico. Fue una decisión que anunciaba una nueva manera de relacionarse con la pintura. En 1623, el mismo año en que llegó Velázquez a Madrid, esos cuadros estaban ya en el Alcázar, donde los vio el cronista Gil González Dávila. Allí se colocaron en el llamado "Cuarto bajo de verano", un grupo de habitaciones situadas en la parte norte del palacio. Se habían habilitado en ese año para acoger a la familia real durante el caluroso verano de Madrid y evitar que tuviera que trasladarse forzosamente a El Escorial. ${ }^{17}$ Esas estancias, destinadas a la intimidad del rey, se decoraron con una mezcla de retratos familiares y de pintura mitológica (prin-

16. Falomir (2003: 231 y ss.); Checa (2013: 345 y ss.).

17. Volk (1981). 
cipalmente de Tiziano). Por sus temas y los pintores representados, se puede considerar el primer modelo a partir del cual se desarrollaría el personalísimo gusto coleccionista de Felipe IV y su corte. La operación en su conjunto anuncia, asimismo, un gusto por la pintura y un hedonismo que diferenciarían el reinado de Felipe IV del de su padre. Pronto se darían ocasiones para ampliar la colección del rey con grandes obras. La ejecución de Rodrigo Calderón no sólo sirvió para quitar de en medio a un oponente político, pues se aprovechó para comprar en su almoneda la espléndida Adoración de los Magos de Rubens (Museo del Prado). ${ }^{18}$ Tras su visita a Madrid en 1628-1629, este pintor se convertiría en uno de los polos en torno a los cuales se organizó la colección real. En ese contexto de incipiente aprecio por la pintura, la aparición de Velázquez en 1623 resultó providencial para el rey y el pintor.

\section{Imagen de esplendor}

La imagen del rey era múltiple, al igual que la imagen de la corte. Dependiendo del contexto, podía ser austera o espléndida. En la mayor parte de las ocasiones en las que se describe a Felipe IV en esos años, se llama la atención sobre la riqueza de su vestimenta, y no sobre los rasgos de austeridad de la misma. Eso se debe a que son descripciones de fiestas públicas. Así, para celebrar el domingo de Carnaval de 1623 se hizo una máscara para la cual el rey sacó una librea «de lama de plata bordada de acero pavonado, que era tan rica, que el sastre que la hizo, dice que valía más que todas juntas, por el valor y costa que tenía». ${ }^{19}$ Tanto Felipe IV como Olivares llevaron «muchas y grandes plumas azules con rosetas blancas, y en los sombreros dos rosas de diamantes de inestimable valor y precio». Hay que señalar que tal demostración de lujo tuvo lugar apenas dos semanas después de que se dictaran las leyes antisuntuarias que prohibieron los cuellos de lechuguilla. Diez días después, sin embargo, se decidió escenificar el mensaje de austeridad que transmitían esas disposiciones, y el rey y su hermano don Carlos acudieron públicamente a oír misa al colegio de Santo Tomás llevando valonas para dar ejemplo a la corte.

Las alusiones al lujo indumentario del rey se multiplican. Cuando hizo un paseo público con el príncipe de Gales entre San Jerónimo y Palacio llevaba "un vestido pardo, todo cuajado de bordaduras de oro, tan rico, cuanto llano»; ${ }^{20}$ y cuando el domingo de Pascuas de ese mismo año de 1623 salió a escuchar vísperas, llevaba "Tusón grande, y una cadena atravesada, que pudiera cerrar el puerto del Coloso (...) En el sombrero, cintillo y joya de diamantes». ${ }^{21}$ Unas

18. Vergara (1999: 63 y ss.).

19. Máscara y fiesta... 1623, p. 191.

20. Relación del gran recibimiento... 1623, p. 200.

21. Almansa, Máscara... 1623, p. 210. 
semanas después, a la procesión del Corpus acudió «con gran devoción, vestido de noguerado bordado de oro y todos los botones de diamantes y el Toisón por los hombros». ${ }^{22}$ Ese lujo no tenía por único objeto impresionar y agasajar al príncipe inglés, pues se extendió a actos que tuvieron lugar en los meses y años siguientes. Así, durante el bautizo de su hija Margarita, a finales de 1623, estaba vestido de «negro, y botones de oro, con diamantes, y muchas plumas»; ${ }^{23} \mathrm{y}$ cuando, en 1626, fue a recibir al cardenal Barberini, acudió también «de negro, oro y inestimables joyas de diamantes». ${ }^{24}$

Varias pinturas nos ayudan a imaginar el aspecto del rey y su corte en esas ocasiones. Un conocido cuadro de Juan de la Corte, por ejemplo, nos muestra las riquísimas galas que lucieron los caballeros que participaron en unos juegos caballerescos en la Plaza Mayor para agasajar al príncipe de Gales (Madrid, Museo Municipal). Varios retratos de Felipe IV lo representan con una indumentaria similar a la que se cita en las descripciones anteriores. Uno de ellos (Madrid, Colección particular, Fig. 5) muestra al rey de gala, con una riquísima botonadura de diamantes y una pesada cadena de oro que le atraviesa el pecho. Su rostro sigue el prototipo creado por Velázquez, lo que se explica teniendo en cuenta que al pintor se le concedió el monopolio de la imagen del rey. ${ }^{25}$ Una copia de este retrato fue a parar a manos del cardenal Sachetti, que acompañó a Barberini en su viaje de vuelta a Italia. ${ }^{26}$ Un énfasis en la riqueza indumentaria aparece también en otro retrato de Felipe IV (Madrid, Instituto Valencia de Don Juan), del que se ha sugerido una atribución a Van der Hamen, y que es muy interesante desde el punto de vista tipológico, pues en él se mezcla la imagen del rey de gala con la imagen del rey que atiende a sus responsabilidades de gobernante, como atestigua el bufete sobre el que apoya la mano izquierda y el papel que sostiene en la derecha. ${ }^{27}$ Riqueza y responsabilidad se mezclan también en dos retratos parecidos en los que aparece el rey con una suntuosa armadura, alusiva a sus deberes militares. Su atribución es incierta y ha basculado entre Gaspar de Crayer y Maíno (Fig. 6). ${ }^{28}$

22. Noticias 1942, p. 639.

23. Peña 1623 , p. 277.

24. Peña 1626, p. 347.

25. Se dio a conocer en Dallas (2012: 110).

26. Salort (2001).

27. Jordan (2005: 211-212).

28. Ruiz (2009: 191). 


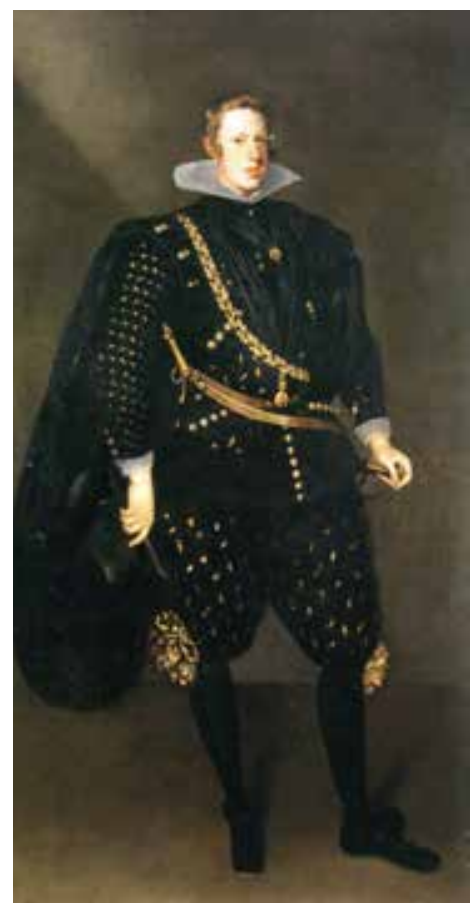

Figura 5.

Anónimo, Felipe IV, h. 1625, Madrid, Colección particular.

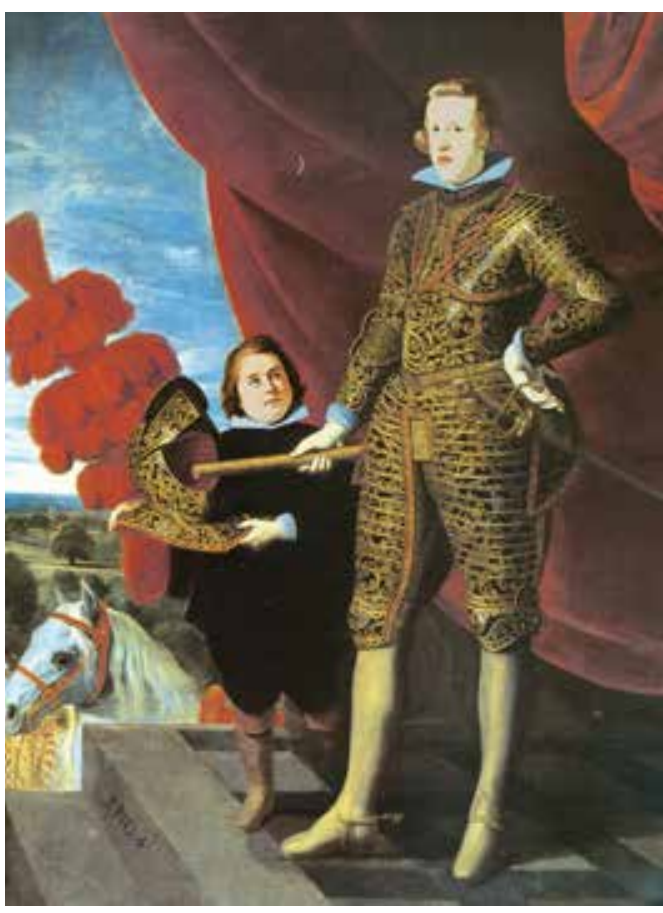

Figura 6.

Pintor activo en Madrid h. 1624, Felipe IV, Madrid, Ministerio de Asuntos Exteriores.

Todas ellas son obras fácilmente relacionables con los retratos de Felipe IV anteriores a las leyes antisuntuarias de 1623. Es el caso ya mencionado que lo representa todavía príncipe, acompańado por el enano Soplillo y ostentando no sólo un costoso cuello de lechuguilla, sino también el tipo de calzas que se suprimieron al poco de acceder al trono (Fig. 1). Del mismo autor, Rodrigo de Villandrando, es un retrato fechado en 1622 (Estados Unidos, Colección particular) que muestra al rey de tres cuartos, sosteniendo un papel con la derecha y apoyando la izquierda en el pomo de la espada, y muy lujosamente vestido. Todas estas imágenes anteriores concuerdan con la imagen que transmitía Felipe IV en sus presentaciones públicas, a juzgar por las descripciones de las mismas.

Sin embargo, en 1623 ocurrió un hecho decisivo que cambiaría la historia del retrato cortesano espańol: el establecimiento de Velázquez en la corte como pintor de Felipe IV, una tarea en la que estuvo empleado hasta su muerte en 1660. A través de las primeras efigies que realizó el pintor del monarca y de su corte entramos en contacto con ideas relacionadas con la imagen real, y entendemos hasta qué punto ésta —en manos de un artista inteligente- pudo 
convertirse en transmisora no sólo de los ideales genéricos de la monarquía, sino incluso de estrategias políticas coyunturales. Pero antes de describir ese proceso, puede ser interesante mostrar de manera general cómo se planteó la relación entre decoro y retrato cortesano en la España de Felipe IV.

\section{Decoro y retrato cortesano}

El retrato del rey y su entorno es uno de los lugares donde se puede estudiar cómo funcionaban algunos de los mecanismos de control y censura, y cómo en la discusión sobre los mismos entraban en juego consideraciones relacionadas tanto con su iconografía como con su calidad. Cuando los pintores madrileños, en torno a 1620, invocaron la protección del rey para la creación de una academia de pintura que sirviera no sólo como marco de estudio y aprendizaje sino también como institución reguladora, uno de sus principales argumentos se relacionaba con el decoro necesario en las imágenes sagradas y en los retratos reales: «Y particularmente les mueve el celo de que su nobilísima y liberal arte de la pintura se ejerza ya con la perfección y valentía que requiere su objeto, en especial en cuanto a hacer imágenes sagradas, y retratos de las personas reales, que por carecer los más de los debidos preceptos, han indecentemente obrado, oscureciendo y turbando el decoro y respeto debido a la grandeza desta absoluta y hermosísima arte». ${ }^{29} \mathrm{~A}$ través de una representación adecuada se buscaba despertar una serie de sentimientos o afectos cuya existencia no estaba garantizada si las obras no se encontraban realizadas según las leyes del arte. Así, en el caso de las imágenes de Cristo (extrapolable a las del rey), los autores del memorial afirman que «También lo es (necesario) que tenga perfección y propiedad, porque si la imagen de Cristo nuestro Señor estando pintada con majestad y hermosura, nos causara reverencia y amor, y si estuviere pintada con fealdad e indecencia, hará efectos contrarios». ${ }^{30}$

Es cierto que no hay que desligar estos comentarios de su contexto, que es el de unos artistas a los que interesaba profundamente controlar el ejercicio de su actividad profesional y demostrar tanto la posibilidad de normativización de su arte como la importancia del mismo para la religión y el estado. También es verdad que desde otros ámbitos surgieron opiniones más laxas, como la de Juan de Zabaleta, para quien «No hay retrato tan malo que no diga algo bueno». ${ }^{31}$ De hecho, abundan los testimonios literarios sobre este debate, con opiniones en muchas ocasiones encontradas. Algunos de ellos tuvieron gran fortuna, como el que incluye Lope de Vega en su Peregrino en su patria, donde se refiere a la contestación relajada de Felipe II cuando le advirtieron que

29. Memorial... 1619, p. 170.

30. Este memorial... 1619, p. 167.

31. Cito por Carducho (1979: 339, nota). 
corrían retratos suyos de baja calidad. ${ }^{32}$ Más allá del tópico literario y de los intereses de los tratadistas, la práctica pictórica durante el siglo XVII, y especialmente en el reinado de Felipe IV, nos dice que existió una conciencia de la necesidad de cuidar la imagen real desde el punto de vista de su contenido y su calidad, y que en algunas ocasiones esa conciencia se hizo explícita y se tradujo en medidas muy concretas.

Los pintores y el público del siglo XviI disponían de un formidable marco, procedente de la Antigüedad, que les permitía resolver la casuística principal de la imagen real. ${ }^{33}$ Se trata de las historias relacionadas con Alejandro Magno y sus retratistas, especialmente Apeles y Lisipo. Apeles, sobre todo, fue un nombre repetido hasta la saciedad en todo tipo de expresión literaria, y su historia tuvo un carácter ejemplar. De su popularidad da prueba el que su relación con Alejandro diera lugar a, al menos, tres obras de teatro: Las grandezas de Alejandro de Lope de Vega, la comedia anónima La mayor hazaña de Alejandro Magno y Darlo todo y no dar nada de Calderón. Esta última fue escrita en 1651 con destino a la corte, para celebrar el nacimiento de la infanta Margarita y la recuperación de Mariana de Austria. Una de sus primeras escenas nos muestra algunas de las cuestiones que entraban en consideración alrededor de los retratos reales, y describe una fórmula que se haría tópica para su resolución. La escena nos muestra a Alejandro Magno determinado a hacerse retratar para corresponder a Roxana, que le había solicitado una efigie suya. Para ello, se convocó a tres retratistas: Timantes, Zeuxis y Apeles, cada uno de los cuales realizó un retrato. El tema sirvió a Calderón para alabar el arte de la pintura y ponderar la importancia que para su desarrollo tiene la protección que recibe de los príncipes:

«Alejandro: Noticias tengo / de la elegancia con que / los tres sutiles, y diestros / ejercéis el mejor arte, / más noble, y de más ingenio

Timantes: Si los príncipes le honraran, / señor, como vos, bien creo / que se adelantaran más / sus artífices

Zeuxis: Y es cierto, / pues sus estudios tuvieran / vuestros honores por premio.

Apeles: Mayormente, cuando fuera, / como ahora, su heroico empleo / vuestra persona; pues ella / hiciera su nombre eterno». ${ }^{34}$

Estos comentarios cortesanos actúan como preámbulo de la elección de Alejandro Magno. Cuando Timantes le enseña su retrato, lo rechaza porque ha faltado a la verdad, disimulando la mancha que tiene en el rostro. También rechaza la obra de Zeuxis, pues ese defecto se muestra de manera muy explícita, lo que le hace decir «lo que en uno es lisonja, / es en otro atrevimiento». Es de su gusto, sin embargo, el de Apeles, pues lo ha representado con un alto grado de parecido

32. Sobre estos temas, ver Herrero García (1936).

33. Martínez Ripoll (2008).

34. Calderón 1991, t. II, p. 1027-1028. 
y de medio perfil, lo que le ha servido para disimular el defecto sin faltar a la verdad. Con ello se subraya que el retrato - y el arte de la pintura en generales un campo en el que intervienen decisivamente factores que van más allá de la capacidad imitativa del pintor, como son el juicio, el ingenio y la discreción.

A la hora de construir esta escena, Calderón manejó libremente las fuentes antiguas, pues mezcló la historia de Apeles y Alejandro con la de Apeles y Antígono, que era quien tenía el defecto en el rostro.

Pero lo que más interesa señalar aquí es que la elección del retrato de Apeles llevó aparejada otra decisión por parte de Alejandro, quien dictaminó que «nadie, sino Apeles, pueda / retratarme desde hoy, siendo / Pintor de Cámara mío». Esa decisión está basada en las fuentes antiguas, que hablan acerca del monopolio sobre su imagen que concedió el emperador a Apeles en lo que se refiere a la pintura y a Lisipo en la escultura. Calderón no necesitaba remontarse a los escritores antiguos, pues no hay tratadista de arte que no se refiera a esa anécdota, presente también en numerosas obras de creación literaria.

Más allá de su condición de tópico literario, la exclusividad dictada por Alejandro sobre su imagen creó un marco de referencia sobre el que modelar una parte de la práctica retratística en las cortes modernas. A través de esa decisión, el rey se aseguraba el control sobre su propia imagen, y no sólo desde el punto de vista de sus contenidos, sino también de su calidad. El caso de Velázquez y Felipe IV resulta altamente significativo tanto de los mecanismos de ese control como del tipo de imagen o imágenes que surgieron de esa dinámica.

\section{Velázquez en la corte}

Tras un primer intento de acercamiento a la corte en 1622, al año siguiente Velázquez viajó a Madrid y con ayuda de algunos conocidos y de su suegro Francisco Pacheco logró llegar hasta el rey, tras orquestar una estrategia muy inteligente. El retrato de Felipe IV (Dallas, Meadows Museum, Fig. 7), o el que hizo del príncipe de Gales (Perdido), colmaron las expectativas de la corte y dieron lugar a un primer encuentro con el conde duque de Olivares. Conocemos el episodio a través del tratado de Francisco Pacheco, quien aseguró que Olivares le «alentó a la honra de la patria», lo que es índice de la consideración del retrato como instrumento político. Además, le prometió «que él sólo había de retratar a su majestad, y los demás retratos se mandarían recoger». ${ }^{35}$ Esa relación se formalizó con el nombramiento de Velázquez como pintor del rey el 30 de octubre de 1623 . No hay que leer el término "promesa» en sentido estricto, puesto que el conde duque no necesitaba comprometer la exclusividad de la imagen real ante un pintor joven que deseaba entrar al servicio del rey. Pacheco vuelve a referirse a un episodio parecido cuando, tras narrar el primer viaje de su yerno a Italia, comenta que a

35. Pacheco 1990, p. 205. 
su vuelta «fue muy bien recibido del conde duque, mandóle fuese luego a besar la mano a Su majestad, agradeciéndole mucho no haberse dejado retratar de otro pintor, y aguardándole para retratar al príncipe, lo cual hizo puntualmente». ${ }^{36} \mathrm{Se}$ trata del príncipe Baltasar Carlos, que había nacido durante la ausencia de Velázquez. Se sabe que en ese tiempo se hizo al menos un retrato del niño; ${ }^{37}$ al igual que se hizo un retrato de la nueva reina Mariana de Austria cuando Velázquez estuvo ausente por segunda vez en Roma, en 1650. Por eso, la afirmación de Pacheco no hay que tomarla estrictamente al pie de la letra, sino interpretarla de forma laxa, dentro de la estrategia que utilizó para recalcar las relaciones de favor entre Felipe IV y su yerno. Por otra parte, aunque hubo retratos del rey y su entorno que escaparon del control de Velázquez, la imagen que se fue creando del mismo a lo largo de las décadas tiene una impronta genuinamente velazqueńa.

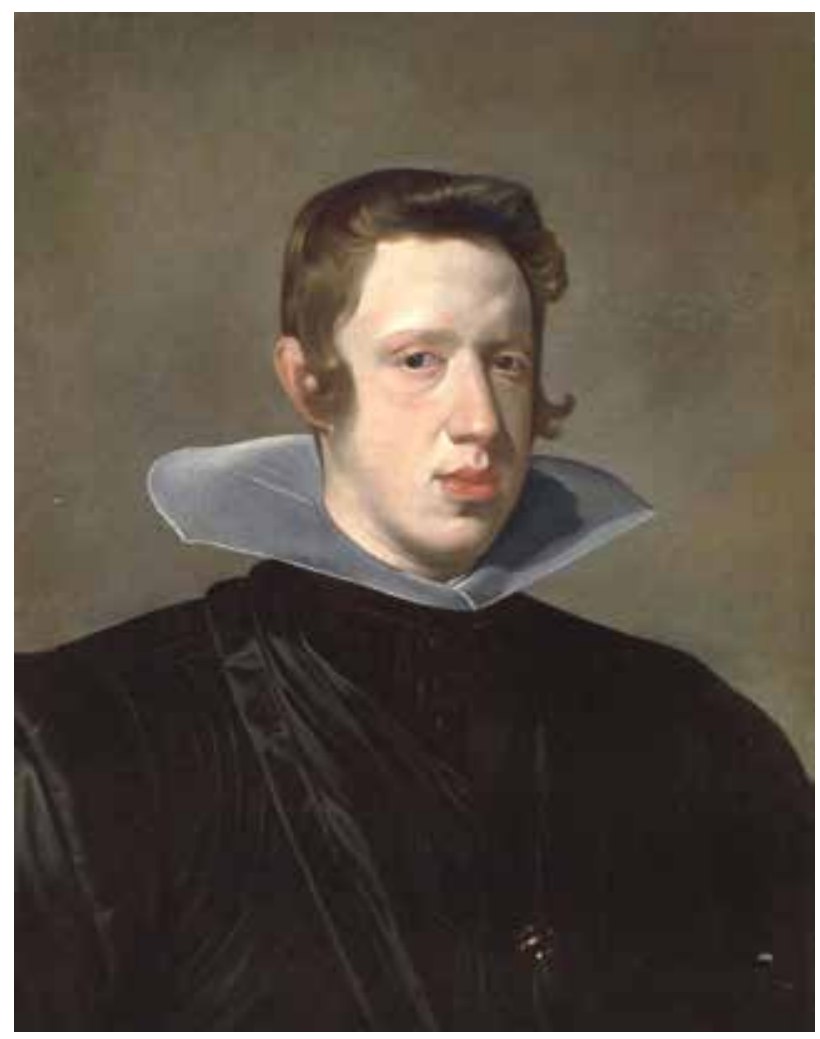

Figura 7.

Diego Velázquez, Felipe IV, 1623, Dallas, Meadows Museum.

36. Idem, p. 209

37. Morán y Rudolf, p. 293 
La adopción como retratista real de un pintor joven, prometedor e inmerso en un círculo de relaciones próximo al conde duque de Olivares constituyó un paso fundamental para modelar la imagen del rey al gusto del propio monarca y de su valido, y de asegurarse el control de su difusión. De hecho, los primeros retratos de Felipe IV por Velázquez reflejan de manera muy precisa los ideales reformistas con que se inició su reinado (Fig. 8). Para entender lo que significan, es necesaria su comparación con los retratos relacionados con Villandrando, Van der Hamen o Maíno a los que nos hemos referido anteriormente, y que continúan la tradición de la retratística de Felipe III en lo que se refiere a lujo indumentario y a composición. ${ }^{38}$

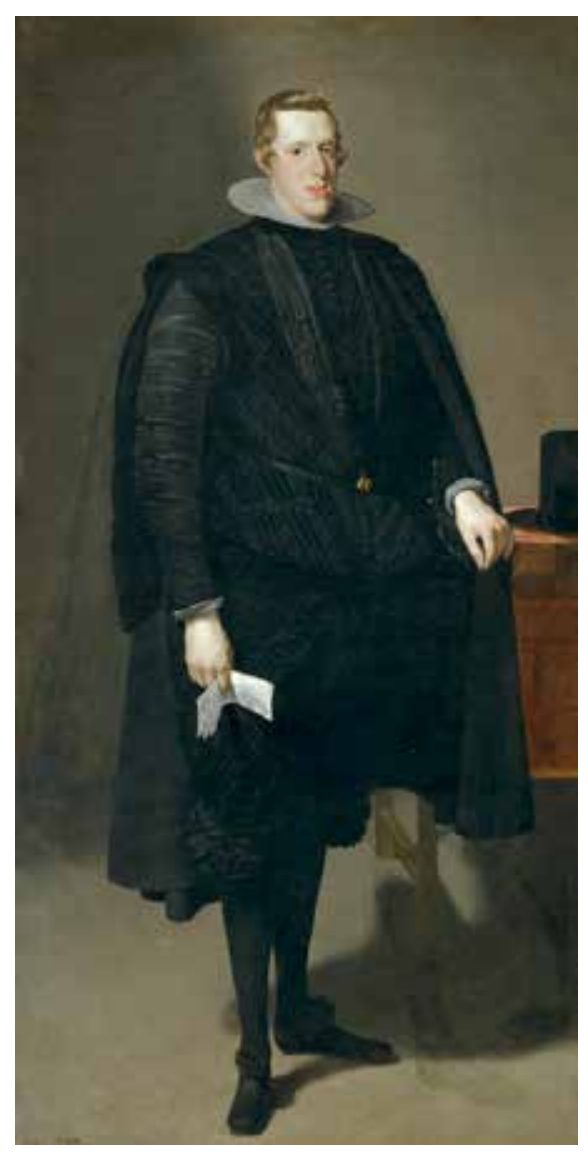

Figura 8.

Diego Velázquez, Felipe IV, h. 1623-1628, Madrid, Museo Nacional del Prado.

38. Portús (2012) 
Estos primeros retratos de Velázquez que tienen como modelos a Felipe IV, su hermano Carlos, o el conde duque de Olivares se resuelven en todos los casos en términos de sobriedad y contención. En su representación se huye de los signos de ostentación indumentaria (aunque no faltan alusiones al estatus), y mediante una gama cromática limitada y extraordinariamente sutil, amén de un uso maestro de la iluminación, se transmite una imagen de control, trabajo y responsabilidad, más que de fasto y riqueza. Ya no estamos ante el rey o el ministro que hace su aparición por las calles de Madrid para participar en algún espectáculo caballeresco o una procesión, o para recibir a algún visitante ilustre. Estamos, en cambio, ante hombres de estado que asumen sus responsabilidades. En el caso de los retratos de Felipe IV, su indumentaria oscura y su posición cercana a un bufete coincide con la forma en que se presentaba para dar audiencia, que era una de sus principales obligaciones cotidianas ${ }^{39}$ y que atendía en pie, con el collar del Toisón, arrimado a un bufete. Es el «rey trabajando»; y para subrayar esa faceta, Velázquez utiliza dos recursos. Por un lado, el papel que sostiene el rey en su mano derecha, y que hace alusión a los memoriales que se le presentaban cuando daba audiencia. Por otra parte, la ausencia de costosos adornos en el vestido o de joyas nos habla del ideal de austeridad, racionalidad, reformismo y trabajo con los que nació el nuevo reinado. Pocas veces en la historia del retrato cortesano se ha logrado crear un tipo de imagen que refleje de manera tan eficaz un cambio tan drástico en la forma de concebir el ejercicio del poder.

La gran pregunta reside en decidir si se trata de una creación personal de Velázquez, quien sabría percibir los nuevos aires que corrían en la corte y traducirlos al campo del retrato; o, si, por el contrario, fue una fórmula inducida. Probablemente no hay una respuesta absoluta, y estos retratos nacieron como resultado de una interacción entre el pintor y su medio.

39. Mártir Rizo (1626) 1945, pp. 115 y ss. 
